\title{
FACTORS CONTRIBUTING TO CHRONIC URTICARIA/ANGIOEDEMA AND NUMMULAR ECZEMA RESOLUTION - WHICH FINDINGS ARE CRUCIAL?
}

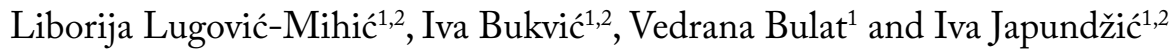 \\ ${ }^{1}$ Department of Dermatovenereology, Sestre milosrdnice University Hospital Centre, Zagreb, Croatia; \\ ${ }^{2}$ School of Dental Medicine, University of Zagreb, Zagreb, Croatia
}

\begin{abstract}
SUMMARY - When working with dermatology patients, the question sometimes arises which diagnostic tests and tools should be used for workup, particularly in cases of chronic urticaria (CU) and discoid nummular eczema, where the treatment of associated systemic diseases and infections may be crucial for patient outcome. The aim was to investigate retrospectively the influence of associated diseases on skin disease outcomes based on medical records of CU and nummular eczema patients in comparison to controls. We included patients admitted to our Dermatology Department over a 6-year period and analyzed their laboratory findings, related factors and outcomes recorded after two years of workup and treatment. Compared to controls, $\mathrm{CU}$ patients had a significantly higher prevalence of positive Helicobacter (H.) pylori findings $(\mathrm{p}=0.020)$, confirmed allergies $(\mathrm{p}=0.006)$, increased $\mathrm{IgE}$ $(\mathrm{p}=0.011)$ and pathologic thyroid findings $(\mathrm{p}=0.049)$, whereas nummular eczema patients only had significantly higher positive $H$. pylori findings ( $\mathrm{p}=0.046$ ). Meaningful regression of both dermatoses was recorded after treatment of associated diseases, with significant benefit from $H$. pylori treatment. This indicated that the diagnosis of associated infections (particularly H. pylori and urogenital infections), confirmed allergies, endocrine disorders (particularly of thyroid gland in $\mathrm{CU}$ patients) and serum malignancy markers could play a crucial role, as their treatment may improve disease outcomes.

Key words: Chronic urticaria; Diagnostic techniques and procedures; Eczema; Helicobacter pylori; Skin diseases; Croatia
\end{abstract}

\section{Introduction}

When working with dermatology patients, the question sometimes arises which diagnostic tests and tools should be used for workup. With some skin diseases, particularly in cases of discoid nummular ecze$\mathrm{ma}$ and chronic urticaria (CU), there is evidence for associated systemic diseases or disorders and infections, so some dermatologists will check for such conditions even as others oppose this approach. Although

Correspondence to: Prof. Liborija Lugović-Mibic, PhD, Department of Dermatovenereology, Sestre milosrdnice University Hospital Centre, Vinogradska c. 29, HR-10000 Zagreb, Croatia

E-mail: liborija@gmail.com

Received January 7, 2019, accepted May 20, 2019 the literature does mention a possible connection with particular associated diseases, there are no clear recommendations on whether they should be tested for at all and, if so, when. In addition, as no sufficient clinical evidence for the influence of diagnostics and treatment of associated conditions has been provided, it remains an open question concerning patients with $\mathrm{CU}$ and nummular eczema.

Typical of CU is the recurrence of hives within a period of six weeks or longer, accompanied by angioedema in about $50 \%$ of cases ${ }^{1}$. Recently, the term spontaneous $\mathrm{CU}$ has been in use, particularly in $\mathrm{Eu}-$ rope, more than the term chronic idiopathic $\mathrm{CU}$, used in the U. S. CU occurs in $1 \%$ of the population; its frequency is higher in adults, particularly in women 
and people aged 30 to $50^{2,3}$. The usual associated diseases are autoimmune diseases and various infections. Evidence for associated malignant disorders is still inconclusive $^{4,5}$. Diagnosis is based on clinical manifestations along with laboratory and diagnostic tests, e.g., autologous serum skin test (ASST).

Nummular eczema (synonyms: nummular or discoid dermatitis), discovered by Marie Guillaume Alphonse Devergie in the $19^{\text {th }}$ century, is characterized by discoid skin lesions commonly on the extremities (particularly legs), but also elsewhere (trunk, hands, face, and neck) ${ }^{6,7}$. Clinically recognizable manifestations are pruritic skin with coin-shaped erythematous patches, with papules and vesicles in the acute phase and crusts and desquamation in the chronic phase ${ }^{7}$. Men usually get nummular eczema late in life, whereas women get it at a younger age ${ }^{7}$. The etiologic cause of the disease is unclear but is considered to be multifactorial with many possible triggers and related factors such as atopic dermatitis (AD), dry skin, mental stress, weather conditions, infection and alcohol ${ }^{6,7}$. Nummular eczema often takes a chronic and recurrent course.

As the association and influence of different factors and diseases possibly related to $\mathrm{CU}$ and nummular eczema outcome have been underexplored, we decided to carry out this study and research them.

\section{Subjects and Methods}

\section{Subjects}

We conducted a retrospective study to investigate the prevalence of associated diseases recorded and their characteristics in patients with $\mathrm{CU}$ and nummular eczema on the basis of medical records and in comparison to control subjects. We included patients admitted to the Dermatology Department, including outpatients, over a 6-year period (January 1, 2010 to December 31, 2015) and recorded their laboratory findings, related factors and outcomes recorded after two years of workup and treatment. Only patients with complete medical records containing evidence required for diagnosing a dermatosis or an associated disease were taken into consideration.

We included CU patients treated with H1-antihistamines, while excluding those having received systemic immunosuppressant therapy (cyclosporine, montelukast, omalizumab, and others), patients with chronic inducible urticaria, drug-induced urticaria/angioedema, and those taking systemic corticosteroids at long-term. Another group included patients with nummular eczema treated with topical corticosteroid preparations and systemic antihistamines, excluding those with $\mathrm{AD}$ (diagnosed by Hanifin-Rajka criteria) and asteatotic dermatitis. Finally, 30 adult control subjects with vulgar psoriasis were included as controls. All participants signed a written informed consent, and the study was conducted according to the Helsinki Declaration guidelines.

\section{Methods}

During the above-mentioned 2-year testing and treatment, medical records of all patients were documented together with their outcomes after that period (regression or persistent disease).

\section{Laboratory tests}

The following tests were carried out in all three groups: complete blood count (CBC) with differential blood count (DBC), erythrocyte sedimentation rate (ESR), C-reactive protein (CRP), urine (when bacteriuria was found, urine cultures, cervical or urethral swabs were performed), glucose (GLC), creatinine, urea, AST, ALT, GGT, ALP, bilirubin, thyroid-stimulating hormone (TSH) levels, free T3 and T4 (thyroid hormones), anti-thyroid peroxidase (antiTPO) and anti-thyroglobulin (antiTg) antibodies, antinuclear antibodies (ANA), total immunoglobulin $\mathrm{E}$ ( $\mathrm{IgE})$, serum protein electrophoresis, rheumatoid factor (RF), LDH, cholesterol, LDL, triglycerides, HDL, anti-streptolysin O (ASO), anti-staphylosin (ASTA), nasal and throat swabs, stool tests for Helicobacter pylori (H. pylori), parasites and Candida, perianal tape test for oxyuriasis, rapid plasma reagin (RPR) test, and chest radiography.

Additionally, based on the patient medical history and self-reported symptoms and/or in consultation with colleagues from the related fields, some patients underwent the following laboratory tests: hepatitis B and $\mathrm{C}$ serology, EBV and CMV serology, Koch's bacillus, sputum culture, paranasal sinus radiography, abdominal and pelvic ultrasound, intradermal injection of purified protein derivative of Mycobacterium tuberculosis (PPD) or QuantiFERON test, serum immunoglobulins (IgG, IgA, IgM), HIV-serology test, levels of complement proteins $\mathrm{C} 3$ and $\mathrm{C} 4$, serum tumor marker analyses, and others. 
Allergy skin tests and other skin tests

We performed standard prick tests for aeroallergens and foods by applying allergen solutions to the forearm and patch tests for contact allergens with allergens applied to patient upper back (following the European Society of Contact Dermatitis guidelines) ${ }^{8,9}$. Standard allergen kits supplied by the Institute of Immunology, Zagreb, Croatia, were used ${ }^{8}$. A positive reaction was recorded if the patient was positive to any of the tested allergens. We also performed direct immunofluorescent tests (DIF) to look for urticarial vasculitis; patients having tested positive were excluded from the study, and ASST to examine for potential autoimmune urticaria.

\section{Outcome evidence}

Patients whose laboratory tests revealed irregular findings were referred to their primary doctor for further therapy. Finally, we recorded patient outcomes after two years of initial tests and treatment of dermatoses and related diseases. Resolution was recorded when the patient was free from hives/eczema for at least 6 months.

\section{Statistical analysis}

Differences between individual disease groups (CU and nummular eczema) and the control group were analyzed by Fisher exact test. Results are presented in tables with multiple fields. All p values below 0.05 were considered significant. The IBM SPSS Statistics, version 25 , was used on all statistical analyses.

\section{Results}

The study included $160 \mathrm{CU}$ patients, 110 (68.8\%) women and 50 (31.2\%) men, age range $16-83$, mean age 46.82 years (Table 1$)$. There were 123 nummular eczema patients, 78 (63.4\%) women and 45 (36.6\%) men, age range $16-95$, mean age 55.57 years (Table 2 ). Control group consisted of 30 patients with vulgar psoriasis (15 male and 15 female, age range 26-89, mean age 51.2 years).

\section{Results in CUpatients}

The most common pathologic deviation was H. pylori infection (33.8\%), followed by positive skin allergy tests $(30.0 \%)$, mostly to contact allergens $(10.0 \%)$ and
Table 1. Comparison of the most common results in patients with chronic urticaria and control group

\begin{tabular}{|l|l|l|l|}
\hline & $\begin{array}{l}\text { Chronic } \\
\text { urticaria } \\
\text { n (\%) }\end{array}$ & $\begin{array}{l}\text { Control } \\
\text { group } \\
\text { n (\%) }\end{array}$ & $\mathrm{p}$ \\
\hline Patients, N & 160 & 30 & \\
\hline Female & $110(68.8 \%)$ & $15(50.0 \%)$ & \\
\hline Male & $50(31.2 \%)$ & $15(50.0 \%)$ & \\
\hline HP infection & $\mathbf{5 4 ( 3 3 . 8 \% )}$ & $4(13.33 \%)$ & $\mathbf{0 . 0 2 0 ^ { * }}$ \\
\hline $\begin{array}{l}\text { Confirmed } \\
\text { allergy }\end{array}$ & $\mathbf{4 8 ( 3 0 . 0 \% )}$ & $2(6.67 \%)$ & $\mathbf{0 . 0 0 6 ^ { * }}$ \\
\hline Elevated IgE & $\mathbf{4 3 ( 2 6 . 9 \% )}$ & $2(6.67 \%)$ & $\mathbf{0 . 0 1 1 ^ { * }}$ \\
\hline UG infections & $40(25.0 \%)$ & $6(20.0 \%)$ & \\
\hline Uroinfection & $15(9.38 \%)$ & $4(13.33 \%)$ & \\
\hline Genital infection & $30(18.75 \%)$ & $2(6.67 \%)$ & \\
\hline Thyroid disorder & $\mathbf{2 7 ( 1 6 . 9 \% )}$ & $1(3.33 \%)$ & $\mathbf{0 . 0 4 9 *}$ \\
\hline $\begin{array}{l}\text { Increased } \\
\text { Candida }\end{array}$ & $\mathbf{1 9 ( 1 1 . 9 \% )}$ & $2(6.67 \%)$ & $<\mathbf{0 . 0 0 1 ^ { * }}$ \\
\hline Positive ANA & $13(8.1 \%)$ & $1(3.33 \%)$ & \\
\hline PositiveASST & $8(5.0 \%)$ & $0(0 \%)$ & \\
\hline
\end{tabular}

*statistically significant results; HP = Helicobacter pylori $; \mathrm{UG}=$ urogenital; ANA = antinuclear antibodies; ASST = autologous serum skin test

Table 2. Comparison of the most common results in patients with nummular eczema and control group

\begin{tabular}{|l|l|l|l|}
\hline & $\begin{array}{l}\text { Nummular } \\
\text { eczema } \\
\text { n (\%) }\end{array}$ & $\begin{array}{l}\text { Control } \\
\text { group } \\
\text { n (\%) }\end{array}$ & $\mathrm{p}$ \\
\hline Patients, N & 123 & 30 & \\
\hline Female & $78(63.4 \%)$ & $15(50.0 \%)$ & \\
\hline Male & $45(36.6 \%)$ & $15(50.0 \%)$ & \\
\hline HP infection & $38(30.9 \%)$ & $4(13.33 \%)$ & $\mathbf{0 . 0 4 6}$ \\
\hline Confirmed allergy & $26(21.1 \%)$ & $2(6.67 \%)$ & \\
\hline Elevated IgE & $17(13.8 \%)$ & $2(6.67 \%)$ & \\
\hline UG infections & $14(11.4 \%)$ & $6(20.0 \%)$ & \\
\hline Uroinfection & $10(8.1 \%)$ & $4(13.33 \%)$ & \\
\hline Genital infection & $9(7.32 \%)$ & $2(6.67 \%)$ & \\
\hline Thyroid. disorder & $4(83.3 \%)$ & $1(3.33 \%)$ & \\
\hline $\begin{array}{l}\text { Increased } \\
\text { Candida }\end{array}$ & $11(8.9 \%)$ & $2(6.67 \%)$ & \\
\hline Positive ANA & $15(12.2 \%)$ & $1(3.33 \%)$ & \\
\hline
\end{tabular}

*statistically significant result; HP = Helicobacter pylori; UG = urogenital; ANA = antinuclear antibodies 
foods (9.38\%), and by elevated $\operatorname{IgE}(26.9 \%)$. Also common were urogenital infections (25.0\%) (Table 1). When bacteriuria was present $(21.25 \%)$, microbiological analysis of urine was conducted and revealed $E s c h-$ erichia coli (E. coli) as the most common cause of urinary tract infection (6.88\%). Ureaplasma was the pathologic finding most commonly isolated in cervical (14.37\%) and urethral (4.38\%) swabs. Some patients had overlapping infections, both genital and urinary tract infection. The next most common serum laboratory findings were thyroid disorders (16.9\%) (antiT$\mathrm{PO}$ in $12.5 \%$ and elevated TSH in $8.13 \%$ ) and positive ANA (8.1\%). Some CU patients also showed elevated blood lipids (7.5\%) and glucose levels (3.1\%). Concerning microbiological findings, elevated stool Candida colonization was recorded in $11.9 \%$, whereas nose and throat swabs showed Staphylococcus as the most frequent pathologic finding (11.25\%). Tumor marker analysis showed elevated CA15-3 in $4.38 \%$, and elevated PSA and CEA in $1.25 \%$ of CU patients.

\section{Results in nummular eczema patients}

For this disease, the most common pathologic deviation was $H$. pylori $(30.9 \%)$, followed by confirmed allergies (21.1\%) and elevated $\mathrm{IgE}$ values (13.8\%). On allergy testing, most patients were positive for cobalt (5.69\%), weed pollen (4.88\%) and mites (4.07\%). The next most common finding was urogenital infection (11.4\%) (Table 2). After finding bacteriuria (24.39\%), according to urine cultures, the most frequent urinary tract infections were triggered by E. coli (5.69\%), and Candida (3.25\%). Looking at cervical/urethral smears, Ureaplasma and Streptococcus were the most frequent finding in women (3.25\%), while only Ureaplasma was commonly found in men (6.5\%). Other serum laboratory findings were less commonly positive, as follows: ANA (12.2\%), elevated blood glucose (4.1\%) and elevated blood lipids (4.1\%). The most frequent endocrine laboratory findings were thyroid disturbances, recorded in 3.3\% (positive antiTPO in $4.88 \%$ and elevated $\mathrm{TSH}$ in $4.88 \%$ ). Tumor marker analyses showed elevated PSA (7.32\%), CA19-9 (3.25\%) and CEA (2.44\%) in nummular eczema patients. Microbiological analyses showed increased stool Candida in some patients (8.9\%), and nose and throat swabs indicated Staphylococcus as the most frequent pathologic finding (14.63\%).

\section{Summary of results in $C U$ and nummular eczema patients}

Statistical analysis of our data for CU and nummular eczema showed no significant differences in age and gender distribution but frequently confirmed associated infections (particularly $H$. pylori and urogenital infections), allergies and increased $\operatorname{IgE}$, endocrine disorders (particularly of thyroid gland in $\mathrm{CU}$ patients) and positive malignancy markers. Thus, in $\mathrm{CU}$ patients the most significant findings were $H$. pylori infection $(\mathrm{p}=0.020)$ [also significant in nummular eczema $\mathrm{pa}-$ tients $(\mathrm{p}=0.046)]$, as well as confirmed allergies $(\mathrm{p}=$ $0.006)$ and accompanying increased $\operatorname{IgE}(\mathrm{p}=0.011)$, and abnormal thyroid gland findings $(\mathrm{p}=0.049)(\mathrm{Ta}-$ bles 1 and 2).

Improvement after 2-year treatment was observed in 117/160 (73.1\%) CU patients (Fig. 1) and 76/123 (61.8\%) nummular eczema patients (Fig. 2). Disease remission after tests and therapy was also significantly more common in the CU group than in the nummular eczema group (73.1\% vs. 61.8\%) (Fig. 3).

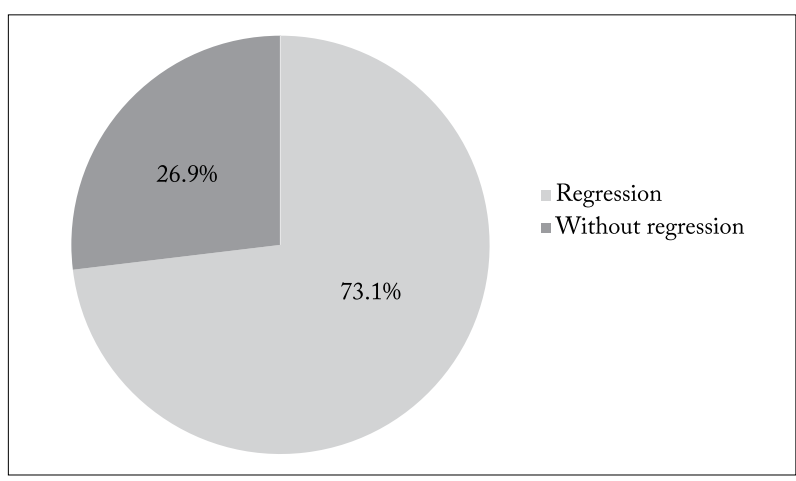

Fig. 1. Regression of chronic urticaria after specific therapy of common associated conditions in these patients.

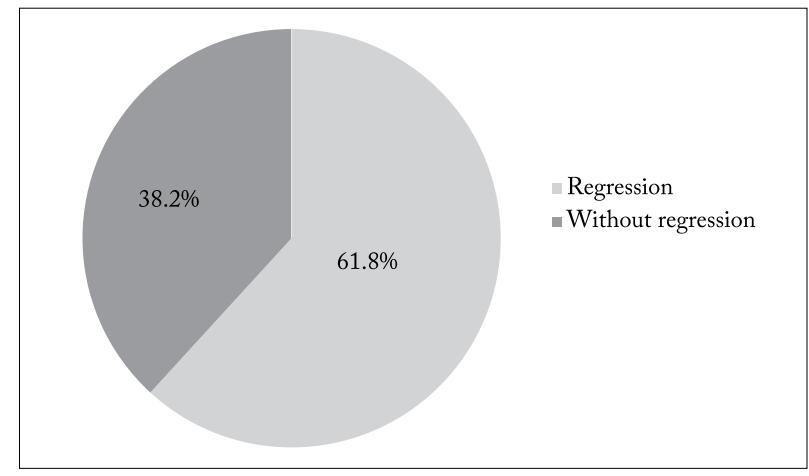

Fig. 2. Regression of nummular eczema after specific therapy of common associated conditions in these patients. 


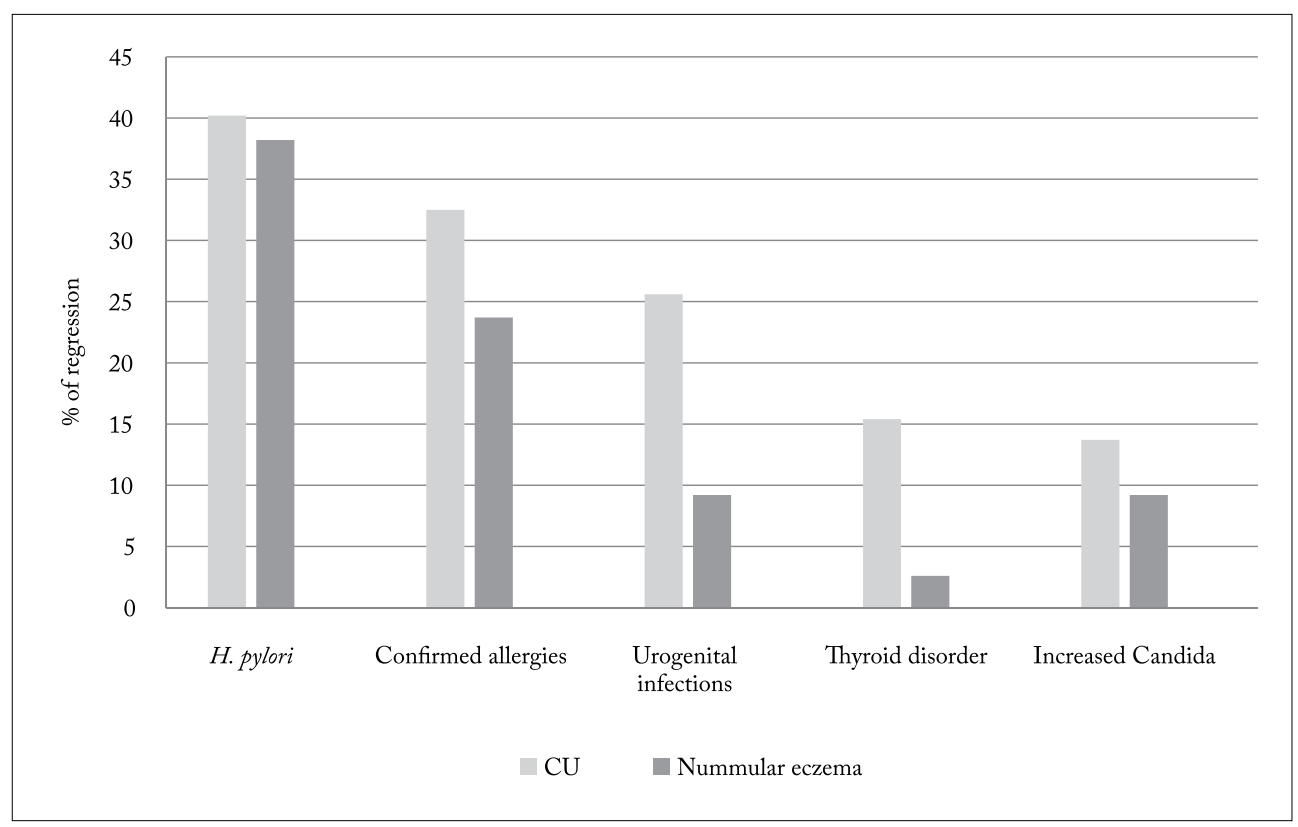

Fig. 3. Percentage of urticarialeczema regression in patients with chronic urticaria or nummular eczema after specific treatment of their associated condition.

In summary, in comparison to controls, CU patients had a significantly higher prevalence of positive H. pylori findings, significantly more confirmed allergies and increased IgE findings and significant pathologic thyroid findings (Table 1). In comparison to controls, nummular eczema patients also had a significantly higher prevalence of positive $H$. pylori findings $(\mathrm{p}=0.046)$. Remarkably, while pathologic thyroid findings were significantly higher in the CU group compared to controls $(16.9 \%$ vs. $3.2 \% ; \mathrm{p}=0.049)$, these findings in the nummular eczema group were nearly the same as in controls $(3.3 \%$ vs. $3.2 \%$; $=1.000)(\mathrm{Ta}-$ ble 2). On the other hand, the controls (psoriatic patients) had a significantly higher prevalence of elevated blood glucose levels (CU p=0.011 and nummular eczema $\mathrm{p}=0.029$ ) and higher cholesterol and LDL findings (CU $\mathrm{p}<0.001$ and nummular eczema $\mathrm{p}<0.001$ ) compared to both patient groups.

\section{Discussion}

Urticaria is one of the most common dermatologic and allergic diseases, with varied etiopathogenetic mechanisms and triggers ${ }^{10}$. In recent years, CU has been increasingly perceived as a systemic disorder that includes systemic immune processes manifesting pri- marily on the skin, and associated with different diseases/dysfunctions (autoimmune diseases, atopy, infections, metabolic conditions, neoplastic disorders, etc. $)^{10-12}$. According to a recent Brazilian study by Dionigi et al. that included chronic spontaneous urticaria (CSU) patients (follow-up), the main associated diseases diagnosed were, in descending order by frequency, syphilis, parasites and protozoa infections (giardiasis, toxocariasis), H. pylori and urinary infections, tuberculosis and hepatitis $\mathrm{B}$ and $\mathrm{C}^{4}$. Our results are somewhat similar, but they also differed, probably due to geographic and cultural differences. The association between CU and infections can be considered more direct in cases where urticaria disappeared after infection treatment, as observed in urinary infections, parasitosis, hepatitis $\mathrm{C}$ and $H$. pylori infections ${ }^{4}$. According to our results, the most common related factor in CU patients was $H$. pylori, which is in accordance with other authors' observations. According to literature data, $84 \%$ of CU patients demonstrated significant improvement or complete CU remission after $H$. $p y$ lori eradication, in contrast to $45 \%$ of untreated $H$. $p y$ lori positive and $29 \%$ of untreated $H$. pylori negative patients with $\mathrm{CU}^{11}$. Therefore, $H$. pylori infection screening is useful in CU patients, along with eradication when found. However, it is possible that the ben- 
eficial effects of $H$. pylori therapy on CU outcome in patients with recorded infection are predominantly consequences of the combination of medicines included in therapy.

According to our other significant results, confirmed allergies (positive allergy skin tests) and elevated IgE titer (atopy) were also common in CU patients. This connection between $\mathrm{CU}$ and atopic conditions (such as AD) suggests probable similarities in their immunopathogenesis and usefulness of allergy skin tests in CU patients ${ }^{13-26}$. As supported by the literature ${ }^{4}$, and according to our results, urinary and genital infections are also common among the associated diseases; however, concomitant genital infections, especially Ureaplasma (confirmed by cervical/urethral swabs), are often overlooked. Another common finding in CU patients was irregular thyroid function. Although antithyroid antibodies are generally observed in $30 \%$ of CU patients, their presence is not connected with either thyroid gland dysfunction or CU severity or duration ${ }^{13,14}$. Nevertheless, in several cases we observed that detection and treatment of thyroid gland diseases/dysfunctions contributed to $\mathrm{CU}$ resolution, as confirmed by some other researchers ${ }^{14}$.

Regarding autoimmune diseases, studies report that CSU occurrence may be their first manifestation, e.g., systemic lupus erythematosus (SLE), dermatomyositis, polymyositis, Sjögren's syndrome, insulindependent diabetes, rheumatoid arthritis and Still's disease ${ }^{14-17}$. Also, according to literature data, RF and ANA are significantly more prevalent in CSU patients than in the general population, even without clinical symptoms of autoimmune diseases ${ }^{4,18}$. According to extensive research from Israel, women with CU have a much higher incidence of rheumatoid arthritis, Sjögren's syndrome, celiac disease, type 1 diabetes mellitus and $\mathrm{SLE}^{16}$. Therefore, it is necessary to be aware that urticaria can precede symptoms of these other diseases by several years, as discussed in the study by Dionigi et al. ${ }^{4}$.

Sometimes other infectious and parasitic diseases such as syphilis and tuberculosis ${ }^{4}$ are observed in CU patients, varying by population and geographic region, although these infectious diseases were less common in our CU patients. According to earlier studies, urticaria disappeared in the majority of patients with parasitosis after specific anti-parasitic treatment (Giardia lamblia, Strongyloides stercoralis, Blastocystis hominis,
Toxocara canis) $)^{1,4}$. Therefore, we encourage taking down detailed histories of infections, particularly gastrointestinal, respiratory and ear-nose-throat (ENT), and dental infections, to conduct reliable routine diagnostic work that includes DBC, CRP, H. pylori examination test and serology for Streptococci, Staphylococci, and Yersinia ${ }^{11,19}$. Also, according to earlier literature, nasal Staphylococcus aureus was more common in CU patients $(53.2 \%)$ than in healthy persons $(13.3 \%)^{20}$, although it was less frequently observed in our study. However, the associated diseases and infections recorded in CU patients are influenced by personal habits and country of origin, which is probably the crucial reason for differences in results. Therefore, if an infection is identified, it should be properly treated, and eradication should be confirmed by follow-up.

Nowadays, diagnostic procedure for $\mathrm{CU}$ is focused on the patient positive history; however, the related diseases may occasionally be asymptomatic and therefore cannot be noted in the history. Thus, expanded testing to determine the cause could save money that would otherwise be spent for long-term therapy. Literature data regarding diagnostics in $\mathrm{CU}$ patients suggest that analysis for CRP, procalcitonin, plasma fibrin degradation products and d-dimer can also yield useful findings ${ }^{26-28}$. Although generally extensive laboratory tests are not recommended, they may be crucial for outcome in particular patients, as urticaria resolution was also recorded after treatment of related diseases, even such as hepatitis B and C and chronic myeloid leukemia ${ }^{4}$. Literature data also show that individuals initially diagnosed with CSU of unknown cause should be longitudinally followed-up, thereby allowing the diagnosis and treatment of associated diseases that develop subsequently ${ }^{29}$.

Unlike CU, nummular eczema is a relatively common dermatosis that is less frequently clinically researched ${ }^{30-33}$. Although its etiopathogenesis is unknown, it is mostly believed to be the result of a contact allergic reaction to bacteria, viruses or fungi. Their antigens likely enter the skin hematogenously from a focal infection, although there is not enough evidence to confirm this definitely. In practice, in the absence of clear guidelines, the diagnosis is mostly based on the clinical picture and manifestations ${ }^{29-33}$. However, related diseases and infections (previously known as 'foci') should also be examined, and many causative factors in its etiopathogenesis can still be taken into 
account, e.g., AD, dry skin, emotional stress, seasonal variations, contact allergies, etc. ${ }^{30-32}$. Epidemiologically, according to literature data, the peak incidence of disease onset is in the third and fourth decades of life (Jiamton et al. report on the mean age of 42.1 years) ) $^{30,31}$ . By gender, studies have shown that two-thirds of affected persons are women ${ }^{30}$. Clinically, nummular eczema lesions predominantly appeared on the upper (75.8\%) and lower (64.5\%) limbs, followed by the trunk, dorsal sides of hands, and on the face and neck ${ }^{31}$.

In diagnostic procedures suitable for nummular eczema patients, histopathologic results are not very useful, as they are similar to those in contact dermatitis, $\mathrm{AD}$, or even lichen and psoriasis ${ }^{33}$. Thus, determination of related diseases and their treatment may be crucial for patient outcome ${ }^{30-37}$. Among the factors that contributed to nummular eczema regression in our study, most important for regression was treatment of $H$. pylori (in 30.9\%), suggesting it should be tested for regularly. The next most frequently found associations were allergies and atopy (increased $\mathrm{IgE}$ determined in 13.8\%), also suggesting an association with atopic constitution. Thus, $14 \%$ of nummular eczema patients had a history of AD and half had a history of atopy or contact dermatitis ${ }^{30}$. Allergy tests carried out in our nummular eczema patients established that contact allergies to cobalt (5.69\%) predominated, followed by allergies to inhalant allergens (weed pollen in $4.88 \%$ and mites in $4.07 \%$ ), indicating that allergens may participate in disease development. Other study results show a significantly higher number of immediate allergic skin reactions to Candida, more frequently observed in elderly subjects as compared to young controls, as well as delayed (contact) allergies ${ }^{36}$. This is also supported by other study results, i.e. contact allergies were observed in $32.5 \%$ of patients, commonly to nickel sulfate $(10.2 \%)$, potassium dichromate $(7.3 \%)$ and cobalt chloride $(6.1 \%)^{30}$. Thus, skin patch testing is strongly advisable in every patient with persistent nummular eczema ${ }^{30,36,37}$. Similarly, patch testing found that elderly patients with nummular eczema retained delayed contact sensitivity at a level comparable to that of the young rather than the age-matched controls (48\%), with common allergies to Dermatophagoides farinae (46\%), house dust (35\%) and Candida albicans $(85 \%)^{36}$.

Urogenital infections were frequently found in nummular eczema patients (11.4\%), mainly by $E$. coli
(5.69\%), and so were genital infections, mainly by Ureaplasma and Streptococcus. Thus, we support regular testing and treatment for these infections in nummular eczema patients. Positive bacteriologic findings (Staphylococcus, Streptococcus) in nose and throat swabs may also be important in some nummular eczema patients as antibiotic treatment may lead to improvement of the skin condition. This argument favors the focus theory ${ }^{33,34}$. Candida may also be an occasional associated factor as large numbers of Candida in stool were observed in $8.9 \%$ of the patients.

Other less common findings in the nummular eczema group included ANA and endocrine findings, suggesting their rare occurrence. Results on serum tumor markers revealed their increase, e.g., PSA, CA199 and CEA, and may indicate malignancies, suggesting a need to monitor these patients for cancer in the future.

The chronic and recurrent nature of nummular eczema, particularly when the cause is not eliminated, may influence the patient's psychological state and affect their quality of life ${ }^{35,38-40}$. For this reason, expanded diagnostics may be helpful, even crucial.

To our knowledge, this is the first study involving a significant number of nummular eczema patients who were analyzed for numerous factors and laboratory tests and whose results were compared with $\mathrm{CU}$ patients and controls. One of the limitations of this study was its retrospective design, which may have specifically affected its usefulness or accuracy.

In conclusion, when working with $\mathrm{CU}$ and nummular eczema patients, the main goal is to achieve lesion resolution, meaning that inclusion of many different diagnostic tools may be crucial. Therefore, the role of a skilled dermatologist and inclusion of laboratory tests are critical and play an essential role in the eventual patient outcomes, particularly determination of associated infections (mainly $H$. pylori and urogenital), confirmed allergies, endocrine disorders (particularly of thyroid gland in CU patients), and malignancy markers.

\section{References}

1. Zuberbier T, Aberer W, Asero R, Abdul Latiff A H, Baker D, Balimer-Weber B, et al. The EAACI/GA(2) LEN/EDF/WAO guideline for the definition, classification, diagnosis, and management of urticaria: the 2013 revision and update. Allergy. 2014;69(7):868-87. doi: 10.1111/all.12313. 
2. Najib U, Bajwa ZH, Ostro MG, Sheikh J. A retrospective review of clinical presentation, thyroid autoimmunity, laboratory characteristics, and therapies used in patients with chronic idiopathic urticaria. Ann Allergy Asthma Immunol. 2009; 103(6):496-501. doi: 10.1016/S1081-1206(10)60266-9.

3. Lapi F, Cassano N, Pegoraro V, Cataldo N, Heiman F, Cricelli $\mathrm{I}$, et al. Epidemiology of chronic spontaneous urticaria: results from a nationwide, population-based study in Italy. Br J Dermatol. 2016;174(5):996-1004. doi: 10.1111/bjd.14470.

4. Dionigi PCL, Menezes MCS, Forte WCN. A prospective tenyear follow-up of patients with chronic urticaria. Allergol Immunopathol (Madr). 2016;44(4):286-91. doi: 10.1016/j.aller. 2015.10.004.

5. Chen YJ, Wu CY, Shen JL, Chen TT, Chang YT. Cancer risk in patients with chronic urticaria: a population-based cohort study. Arch Dermatol. 2012;148(1):103-8. doi: 10.1001/archdermatol.2011.682.

6. Iwahira Y, Nagasao T, Shimizu Y, Kuwata K, Tanaka Y.Nummular eczema of breast: a potential dermatologic complication after mastectomy and subsequent breast reconstruction. Plast Surg Int. 2015;209458. doi: 10.1155/2015/209458

7. Poudel RR, Belbase B, Kafle NK. Nummular eczema. J Community Hosp Intern Med Perspect. 2015;5(3):27909 doi: 10.3402/jchimp.v5.27909

8. Budimir J, Mravak-Stipetić M, Bulat V, Ferček I, Japundžić I, Lugović-Mihić L. Allergic reactions in oral and perioral diseases - what do allergy skin test results show? Oral Surg Oral Med Oral Pathol Oral Radiol. 2019;127(1):40-48. doi: 10.1016/j.oooo.2018.08.001.

9. Japundžić I, Vodanović M, Lugović-Mihić L. An analysis of skin prick tests to latex and patch tests to rubber additives and other causative factors among dental professionals and students with contact dermatoses. Int Arch Allergy Immunol. 2018;5: 1-7. doi: 10.1159/000490181.

10. Darlenski R, Kazandjieva J, Zuberbier T, Tsankov N. Chronic urticaria as a systemic disease. Clin Dermatol. 2014;32(3): 420-3. doi: 10.1016/j.clindermatol.2013.11.009.

11. Wedi B, Raap U, Wieczorek D, Kaap A. Urticaria and infections. Allergy Asthma Clin Immunol. 2009;5:10. https://doi. org/10.1186/1710-1492-5-10

12. Magen E, Mishal J. Possible benefit from treatment of Helicobacter pylori in antihistamine-resistant chronic urticaria. Clin Exp Dermatol. 2013;38(1):7-12. doi: 10.1111/j.1365-2230. 2012.04467.x.

13. Wan KS, Wu CS. The essential role of anti-thyroid antibodies in chronic idiopathic urticaria. Endocr Res. 2013;38:85-8. doi: 10.3109/07435800.2012.714432.

14. Kolkhir P, Metz M, Altrichter S, Maurer M. Comorbidity of chronic spontaneous urticaria and autoimmune thyroid diseases: a systematic review. Allergy. 2017;72(10):1440-60. doi: 10.1111/all.13182.

15. Konstantinou GN, Asero R, Ferrer M, Knol EF, Maurer M, Raap U, et al. EAACI taskforce position paper: evidence for autoimmune urticaria and proposal for defining diagnostic criteria. Allergy. 2013;68(1):27-36. doi: 10.1111/all.12056.

16. Confino-Cohen R, Chodick G, Shalev V,Leshno M, Kimhi O, Goldberg A. Chronic urticaria and autoimmunity: associations found in a large population study. J Allergy Clin Immunol. 2012;129:1307-13. doi: 10.1016/j.jaci.2012.01.043.

17. Cho CB, Stutes SA, Altrich ML, Ardoin SP, Phillips G, Ogbogu PU. Autoantibodies in chronic idiopathic urticaria and non urticarial systemic autoimmune disorders. Ann Allergy Asthma Immunol. 2013;110:29-33. doi:10.1111/j.1365-2133. 2004.06042.x

18. Stitt JM, Dreskin SC. Urticaria and autoimmunity: where are we now? Curr Allergy Asthma Rep. 2013;13(5):555-62. doi: 10.1007/s11882-013-0366-8.

19. Buss YA, Garrelfs UC, Sticherling M. Chronic urticaria which 300 clinical parameters are pathogenetically relevant? A retrospective 301 investigation of 339 patients. J Dtsch Dermatol Ges. 2007;5:22-9. doi:10.1111/j.1610-0387.2007.06194.x

20. Ertam I, Biyikli SE, Yazkan FA, Aytimur D, Alper S. The frequency of nasal carriage in chronic urticaria patients. J Eur Acad Dermatol Venereol. 2007;21:777-80. doi: 10.1111/j. 1468-3083.2006.02083.x

21. Bohme M, Lannero E, Wickman M, Nordwall SL, Wahlgren CF. Atopic dermatitis and concomitant disease patterns in children up to two years of age. Acta Derm Venereol. 2002; 82:98-103. doi:10.1080/00015550252948112

22. Aberle N, Kljaić Bukvić B, Blekić M, Vučković M, Bardak D, et al. Allergic diseases and atopy among schoolchildren in eastern Croatia. Acta Clin Croat. 2018;57(1):82-90. doi:10.20471/ acc.2018.57.01.09.

23. Ćosićkić A, Skokić F, Selimović A, Mulić M, Suljendić S, Dedić $\mathrm{N}$, et al. Development of respiratory allergies, asthma and allergic rhinits in children with atopic dermatitis. Acta Clin Croat. 2017;56(2):308-317. doi: 10.20471/acc.2017.56.02.15.

24. Lugović L, Lipozenčić J, Jakić-Razumović J. Atopic dermatitis: immunophenotyping of inflammatory cells in skin lesions. Int J Dermatol. 2001; 40: 489-94. doi: 10.1046/j.1365-4362.2001. 01203.x.

25. Lugović L, Lipozenčić J, Jakić-Razumović J. Prominent involvement of activated Th1-subset of T-cells and increased expression of receptor for IFN-gamma on keratinocytes in atopic dermatitis acute skin lesions. Int Arch Allergy Immunol. 2005;137(2):125-33. doi: 10.1159/000085468.

26. Lugović-Mihić L, Krišto M, Ferček I, Bukvić I, Duvančić T. Primjena omalizumaba kod kronične spontane urtikarije/angioedema: preporuke, iskustva i spoznaje. Acta Med Croat. 2018;72:495-502.

27. Kasperska-Zajac A, Grzanka A, Machura E, Mazur B, Misiolek M, Czecior E, et al. Analysis of procalcitonin and CRP concentrations in serum of patients with chronic spontaneous urticaria. Inflamm Res. 2013;62:309-12. doi: 10.1007/s00011012-0580-1.

28. Takahagi S, Mihara S, Iwamoto K, Morioke S, Okabe T, Kameyoshi $\mathrm{Y}$, et al. Coagulation/fibrinolysis and inflammation 
markers are associated with disease activity in patients with chronic urticaria. Allergy. 2010;65:649-56. doi: 10.1111/j.1398 -9995.2009.02222.x.

29. Martínez-Blanco J, García-González V, González-García J, Suarez-Castanon. Nummular dermatitis: report of two cases in children. Arch Argent Pediatr. 2016;114(4):e241-4. doi: 10.5546/aap.2016.e241.

30. Jiamton S, Tangjaturonrusamee C, Kulthanan K. Clinical features and aggravating factors in nummular eczema in Thais. Asian Pac J Allergy Immunol. 2013;31(1):36-42.

31. Bonamonte D, Foti C, Vestita M, Ranieri LD, Angelini G. Nummular eczema and contact allergy: a retrospective study. Dermatitis. 2012;23(4):153-7. doi: 10.1097/DER.0b013e3182 $60 \mathrm{~d} 5 \mathrm{a} 0$.

32. Lugović-Mihić L, Ljubešić L, Mihić J, Vuković-Cvetković V, Šitum M. Psychoneuroimmunologic aspects of skin diseases. Acta Clin Croat. 2013;52(3):337-45.

33. Patel N, Mohammadi A, Rhatigan R. A comparative analysis of mast cell quantification in five common dermatoses: lichen simplex chronicus, psoriasis, lichen planus, lupus, and insect bite/allergic contact dermatitis/nummular dermatitis. ISRN Dermatol. 2012;2012:759630. doi: 10.5402/2012/759630.

34. Kim JW, Ko HC, Kim MB, Kim DW, Kim JM, Kim BS. Features of Staphylococcus aureus colonization in patients with nummular eczema. Br J Dermatol. 2013;168(3):658-60. doi: 10.1111/j.1365-2133.2012.11072.x.
35. Olze H, Zuberbier T. Comorbidities between nose and skin allergy. Curr Opin Allergy Clin Immunol. 2011;11:457-63. doi: 10.1097/ACI.0b013e32834a9764.

36. Lugović-Mihić L. The increase in Croatia's scabies incidence: how did refugees and traveling contribute? Travel Med Infect Dis. 2019;29:74. doi: 10.1016/j.tmaid.2019.02.002.

37. Aoyama H, Tanaka M, Hara M, Tabata N, Tagami H. Nummular eczema: an addition of senile xerosis and unique cutaneous reactivities to environmental aeroallergens. Dermatology. 1999;199(2):135-9. doi:10.1159/000018220.

38. Bakula A, Lugović-Mihić L, Šitum M, Turčin J, Šinković A. Contact allergy in the mouth: diversity of clinical presentations and diagnosis of common allergens relevant to dental practice. Acta Clin Croat. 2011;50(4):553-61.

39. Romić Brtan R, Brtan A, Romić I, Cvitanović H, Duvančić, T Lugović-Mihić, L. Quality of life and perception of disease in patients with chronic leg ulcer. Acta Clin Croat. 2015: 54 (3)309-14.

40. Lugović-Mihić L, Pilipović-Knežević K, Crnarić I, Šitum M, Duvančić T. Differential diagnostics of cheilitis. How to classify cheilitis? Acta Clin Croat. 2018;57:342-51. doi: 10.20471/ acc.2018.57.02.16.

41. Novak-Bilić G, Vučić M, Japundžić I, Meštrović-Štefekov J, Stanić-Duktaj S, Lugović-Mihić L. Irritant and allergic contact dermatitis - skin lesion characteristics. Acta Clin Croat. 2018;57(4):713-20. doi: 10.20471/acc.2018.57.04.13.

\title{
Sažetak \\ ČIMBENICI KOJI DOPRINOSE REGRESIJI KRONIČNE URTIKARIJE/ANGIOEDEMA I NUMULARNOG DERMATITISA - KOJI LABORATORIJSKI NALAZI SU KLJUČNI?
}

\author{
L. Lugović-Mibic, I. Bukvic, V. Bulat i I. Japundžić
}

Tijekom rada s dermatološkim bolesnicima javlja se pitanje koje dijagnostičke testove i postupke koristiti u obradi bolesnika, osobito kod slučajeva kronične urtikarije (KU) i numularnog ekcematoidog dermatitisa, bolesti kod kojih liječenje pratećih bolesti i infekcija može biti značajno za ishod liječenja bolesnika. U ovoj retrospektivnoj studiji istražili smo utjecaj pratećih bolesti na ishod bolesti kože, na temelju medicinske dokumentacije bolesnika s KU i ekcematoidnim dermatitisom koje smo usporedili s kontrolnom skupinom. Uključili smo bolesnike zaprimljene u našu dermatološku kliniku tijekom 6 godina te smo analizirali njihove laboratorijske nalaze, povezane čimbenike i ishode bolesti kože koji su zabilježeni nakon 2 godine praćenja i liječenja. U usporedbi s kontrolnim skupinama bolesnici s KU imali su značajno učestalije pozitivne nalaze na Helicobacter (H.) pylori $(\mathrm{p}=0,020)$, češće potvrđene alergije $(\mathrm{p}=0,006)$, češće povišen $\operatorname{IgE}(\mathrm{p}=0,011)$ i češće patološke nalaze štitnjače $(\mathrm{p}=0,049)$, dok su bolesnici s ekcematoidnim dermatitisom imali značajno učestalije pozitivne nalaze $H$. pylori $(\mathrm{p}=0,046)$. Značajna regresija obiju dermatoza bolesti zabilježena je nakon provedenog liječenja pratećih, uz utvrđenu značajnu korist provedenog liječenja infekcije bakterijom $H$. pylori. To ukazuje na važnost dijagnostike pratećih infekcija (osobito $H$. pylori i urogenitalnih infekcija), potvrđenih alergija, endokrinih poremećaja (osobito štitnjače kod bolesnika s KU) i vrijednosti serumskih tumorskih biljega, kao i njihovog liječenja, što utječe na ishod ovih bolesti kože.

Ključne riječi: Kronična urtikarija; Dijagnostičke tehnike i postupci; Ekcem; Helicobacter pylori; Kožne bolesti; Hrvatska 